\title{
МЕТОДОЛОГІЧНІ ЗАСАДИ ДОСЛІДЖЕННЯ ПСИХОЛОГІЧНИХ ЧИННИКІВ СТАНОВЛЕННЯ ТА ВИЯВІВ ПОЛІТИКО-ПРАВОВОЇ СВІДОМОСТІ ОСОБИСТОСТІ
}

Проаналізовано змістові рівні концептуальних ідей та вихідних положень вивчення психологічних чинників, які впливають на процес і результат активного відображення особистістю політико-правової дійсності та вияви політико-правової свідомості (ППС) особистості в політико-правових ситуаціях. Зроблено необхідні уточнення того психологічного змісту, який вкладається науковцями в такі соціально-психологічні феномени, як "політична і правова культура”, “політична і правова ідентичність”, “політична і правова компетентність”, що традиційно вважаються ознаками розвитку політико-правової свідомості. Розглядається співвідношення цих різновимірних виявів політико-правової свідомості в єдиному семантичному просторі. Специфічні аспекти функціонування свідомості аналізуються під кутом зору низки наукових підходів, зокрема обгрунтовуються положення структурно-змістового, процесуального та феноменологічного підходів у вирішенні людиною життєвих завдань. Показано, що оскільки в кожному з цих наукових підходів відбиваються специфічні аспекти функціонування свідомості, то результатом досліджень стає виділення й специфічних груп соціально-психологічних чинників становлення ППС: структурнозмістовий підхід, який вивчає характеристики наявної системи ставлень людини до дійсності, дає змогу виділити структурно-змістові чинники становлення ППС; процесуальний, спрямований на вивчення способів конструювання цієї системи, - комунікативні чинники становлення ППС; феноменологічний, орієнтований на визначення надситуативних характеристик функціонування особистості як суб' єкта політико-правового самовизначення, - функціональні чинники становлення ППС. 3 огляду на результати проведеного аналізу виділено три групи соціально-психологічних чинників становлення політико-правової свідомості: структурно-змістові, комунікативні та функціональні.

Ключові слова: вияви політико-правової свідомості, чинники становлення політико-правової свідомості, політико-правова культура, політико-правова ідентичність.

Z. F. Sivers

\section{METHODOLOGICAL PRINCIPLES OF THE RESEARCH ON PSYCHOLOGICAL FACTORS OF THE STATEMENT AND MANIFESTATIONS OF POLITICO-LEGAL CONSCIOUSNESS OF PERSONALITY}

There are analyzed the content levels of conceptual ideas and starting points for the research on psychological factors which influence the process and the result of the active personal reflection of politico-legal reality and the manifestations of politico-legal consciousness of the individual in politico-legal situations. There are made the necessary clarifications of the psychological content that scientists put into such socio-psychological phenomena as "political and legal culture", "political and 
legal identity", "political and legal competence", which are traditionally considered as manifestations of the development of politico-legal consciousness (PLC). The comparison of these various manifestations of political-legal consciousness in a common semantic space is analyzed. Specific aspects of the consciousness functioning are analyzed through a number of scientific approaches, among which the provisions of the structural-content, procedural and phenomenological approaches are substantiated in persons life tasks solving. It is shown that since in each of these scientific approaches the specific aspects of the functioning of consciousness are revealed, the result of these studies is also the exudation of specific groups of socio-psychological factors in the PLC formation. So the structural-content approach, which studies the characteristics of the existing system of human attitude to reality, allows to highlight the structuralcontent factors of the PLC formation. Procedural approach, aimed at studying the ways of this system constructing, highlights the communicative factors of the PLC formation. Phenomenological approach, focused on the definition of supersituational characteristics of the individual's functioning as a subject of politico- legal selfdetermination, allows to analyze the functional factors of the PLC formation. Regarding to the above-mentioned statements it is distinguished the three groups of socio-psychological factors of politico-legal consciousness formation: structuralcontent, communicative and functional.

Key words: manifestations of politico-legal consciousness, factors of the politico-legal consciousness formation, politico-legal culture, politico-legal identity.

Постановка проблеми. Початковим етапом організації будьякого дослідження $є$ розв'язання проблеми методології, що полягає в забезпеченні їі повноти (охопленні всіх елементів) та віднаходженні оптимальної конфігурації цих елементів. Поняття “методологія" має два відносно самостійні значення. Перше значення полягає в розумінні методології як теорії організації пізнавального процесу. У такому значенні методологія відображає пізнання в загальній формі, можливості пізнавальних механізмів та взаємозв'язок компонентів конкретного дослідження. Тобто методологія практично не залежить від специфіки конкретного предмета дослідження і $є$ методологією в цілому як загальна логіка пізнання. Друге значення методології пов'язане із системою пізнавальних настановлень і механізмів, які уможливлюють проникнення в суть предмета пізнання з урахуванням його цілей та специфіки предмета пізнання. Адекватною засадам дослідження буде така методологія, яка не просто дає змогу дослідити предмет та узгодити результати пізнання $з$ вихідними ідеями, а й виразити своєрідність предмета дослідження та стратегії його пізнання. У зв'язку з цим відносно самостійного значення набуває проблема вироблення методології соціально-психологічного дослідження психологічних чинників становлення та виявів політико-правової свідомості. 3 огляду на вищезазначене цілком природним першим, початковим етапом нашого дослідження став пошук такої, адекватної предметові дослідження методології. Отож метою статmі є спроба реконструювати хід міркувань у процесі цього пошуку. 
Виклад основного матеріалу дослідження. Політико-правову свідомість ми розглядаємо як процес і результат активного відображення (конструювання) особистістю політико-правової дійсності та створення смислової основи власних політико-правових виборів. Функціями свідомості в такому широкому ії розумінні є відображувальна і породжувальна [1, с. 162]. Відображувальна функція політико-правової свідомості полягає у створенні змістових ставлень особистості до себе і до політико-правової дійсності; породжувальна - у перетворенні ситуації та перетворенні себе як суб'єкта вибору.

Виявами політико-правової свідомості традиційно вважають такі соціально-психологічні феномени, як "політична і правова культура", "політична і правова ідентичність", "політична і правова компетентність" тощо. Під кутом зору завдань нашого дослідження потрібно передусім уточнити той психологічний зміст, який науковці вкладають в зазначені поняття, та з'ясувати співвідношення цих різновимірних виявів політикоправової свідомості в єдиному семантичному просторі.

Політико-правова культура - це одна із складових духовної культури суспільства. Вона являє собою зафіксований у звичаях, традиціях, законах політичний досвід суспільства, досвід взаємодії громадян із суспільством та органами влади. На етапі модернізації суспільства, коли змінюються політична система і норми законодавчої регуляції суспільного життя, виникає потреба і в зміні усталених у соціумі способів відображення політико-правової дійсності, створенні нових моделей участі в політичному житті суспільства. Коли старі культурні зразки втрачають свій адаптаційний потенціал, вони все одно не зникають безслідно - їхня регулятивна функція виявляється в тому, що громадяни мають певні очікування від влади, певним чином оцінюють ііі діяльність та взаємодіють 3 владними органами та інститутами. Отже, навіть у ситуації політичних потрясінь та правової невизначеності будь-яке суспільство залишається носієм свого політико-правового досвіду, суб' єктом політичної культури. У цьому сенсі не може існувати "некультурного" суспільства, бо політична культура і влада, як зазначає М. Фуко, імпліцитно відбиваються в будь-якому феномені соціального життя, впливаючи (безпосередньо чи опосередковано) на дії, думки чи інтенції громадян [2].

У сучасній політології тривалий час розробляється поняття “політичної культури особистості", яке конструюється як феномен засвоєння членом суспільства культурних традицій, норм та зразків розв'язання політико-правових проблем. В умовах існування в державі усталеної системи суспільних уявлень про політичний процес і про належні форми політичної діяльності визначення “політичної культури особистості" може здійснюватися шляхом порівняння індивідуальних переконань, цінностей та способів поведінки досліджуваного з прийня- 
тими в соціумі зразками. У результаті можна зробити певний висновок про ступінь подібності індивідуальних і суспільних конструктів політикоправової дійсності: якою мірою цей суб'єкт інтеріоризує норми політичної культури суспільства. Саме в цьому сенсі можна визначати “рівень політичної культури" особистості.

У ситуації стрімких трансформацій суспільства, коли змінюються і інституалізовані, і неінституалізовані норми владно-підвладної взаємодії в соціумі, дуже складно виділити ті загальноприйняті зразки, щодо яких можна визначати рівень політичної культури індивідуальних чи групових суб'єктів. Коли суспільство “експериментує” з множинністю варіантів розбудови своїх взаємовідносин $з$ владою, індивідуальна особистість мусить визначити (а вже потім підтримувати і змінювати) свою власну позицію щодо політико-правової дійсності. Результатом такого самовизначення (ідентифікації себе щодо політико-правової сфери життя) стає політико-правова ідентичність особистості.

Політико-правова ідентичність. На відміну від поняття “політична культура особистості”, яке відображає ступінь засвоєння індивідом усталених у суспільстві культурних норм і зразків, поняття “політична ідентичність" описує специфіку здійснюваного особистістю вибору своєї моделі політичної дійсності 3 множини всіх тих моделей, які пропонує соціум. Ідентичність особистості розглядають як гіпотетичну психологічну структуру, що феноменологічно виявляється в патернах розв'язання людиною проблем і в найширшому сенсі являє собою суб'єктивну концептуальну модель “себе-у-світі” [3-5]. Політико-правова ідентичність особистості - це специфічний зріз Я-концепції, що об'єктивується в процесі розв'язання людиною проблем у політикоправовій сфері життя. А будь-яке наукове дослідження особливостей Я-концепції людини може здійснюватися лише шляхом вивчення способів вирішення нею певних життєвих завдань, оскільки "потенційне психічне” виявляється в процесі функціонування особистості.

Якщо об'єктом наукового дослідження є специфіка самовизначення особистості в політико-правовій сфері життя, то предметами дослідження можуть бути:

а) структурно-змістові особливості суб'єктивної моделі себе-у-світі: специфіка ментальних репрезентацій суб'єктом політико-правової дійсності (структура і зміст тих уявлень і настановлень, що реалізуються особистістю в певній комунікативній ситуації);

б) динамічні характеристики процесу конструювання суб'єктом комунікації смислових основ свого вибору (суб'єктивні стратегії подолання суперечностей між альтернативними варіантами смислоутворення);

в) “надситуативна”, винесена 3 індивідуального життєвого досвіду, схильність особистості здійснювати певний тип життєвих виборів (інтеграція домінуючих ставлень людини до дійсності, що часто актуа- 
лізується в ході вирішення суб'єктом політико-правових завдань: лояльність, переконаність, активність, патерналізм, патріотизм, політикоправова компетентність, ціннісні пріоритети тощо).

Іншими словами, якщо йдеться про способи вирішення людиною життєвих завдань, то способи наука вивчає з позицій структурнозмістового, процесуального та феноменологічного підходів. Зазначені наукові підходи відрізняються постановкою базового питання і дослідницькими методами, за допомогою яких ці питання вирішуються.

Структурно-змістовий niдxid. Засадничим питанням структурнозмістового підходу є питання про те, як ставиться людина до тих чи тих аспектів реальності. Відповідно, основний метод вивчення цієї суб'єктивної моделі реальності - це різноманітні опитування респондентів про те, яким вони бачать чинний і бажаний стан політико-правової дійсності. Результатом таких досліджень стають наукові знання про те, як відображаються у свідомості громадян певні події та явища політичного життя суспільства, як громадяни оцінюють та переживають цю реальність і які моделі бажаного чи вірогідного майбутнього вони створюють.

Прочесуальний niдxid. Другий науковий підхід до вивчення способів політико-правового самовизначення особистості спрямований на дослідження не так змісту набутої нею ідентичності, як перебігу самого процесу ідентифікації. У цьому “процесуальному” підході базовим $\epsilon$ питання про те, як суб'єкт вибору приходить до того чи того рішення (як долає суперечності, що актуалізуються в процесі смислоутворення). Методом вивчення суб'єктивних стратегій смислоутворення є включене спостереження: дослідник і досліджуваний стають учасниками спільної діяльності (інтерактивної взаємодіі), у ході якої об'єктивуються властиві їм патерни долання неоднозначності вибору. Результатом таких досліджень $\epsilon$ наукове знання про способи вирішення особистістю смислотворчих завдань.

Згідно 3 концепцією повноцінного функціонування особистості оптимальним способом смислоутворення є “засвоєння" нею виявлених смислових суперечностей (створення особистісних смислів більш високого порядку, в яких ці суперечності “знімаються"). Існують й інші способи долання виявлених суперечностей, зокрема стратегії "захисту від розвитку", за допомогою яких особистість створює ілюзію, що в неї немає альтернатив вибору. Такі “психологічні захисти” об' єктивуються в самообмеженнях особистості на рівні перцептивних, когнітивних чи творчих можливостей [6;7]. Перспективність процесуального підходу до дослідження феномену політико-правової ідентифікації особистості полягає в тому, що він розкриває психологічну природу суб'єктивних труднощів людини в конструюванні нею життєвих виборів і дає їй орієнтири для оптимізації процесу смислотворчої комунікації. 
Феноменологічний підхід. Крім характеристик суб'єктивного образу дійсності й індивідуальних способів його конструювання, наука вивчає також узагальнену схильність особистості посідати певну позицію, коли йдеться про розв'язання політико-правових проблем. Сумарними виявами таких особистісних схильностей є переживання і дії людини, які науковці категоризують як "патріотизм" (зокрема Е. Андреєв, I. Бех, К. Чорна, П. Віндюк), “патерналізм” (М. Колоколова, С. Літвіна, В. Мяленко), “громадянськість” (В. Жовтянська, О. Князєв) тощо. Хоч ці феномени активно вивчаються в сучасній соціології, правознавстві, педагогіці і психології, і досі залишається неоднозначним розуміння їхньої психологічної природи. 3 одного боку, їх трактують як психічні стани: почуття, переживання, настрої (Є. Бородін, М. Колоколова, Е. Грицай, М. Ніколко); з другого - як психологічні утворення: особистісні якості, настановлення, спрямованість (Ю. Кокарев, А. Князєв, Н. Хазратова); 3 третього - обмежуються віднесенням їх до ідейних, моральних або світоглядних цінностей (І. Дуранов, Г. Здєрева). Відповідно, різняться i методи дослідження цих соціально-психологічних феноменів, і висновки про їхнє значення й шляхи розвитку. Щоб усунути ці суперечності, потрібно, на наш погляд, здійснити короткий екскурс у загальнопсихологічну теорію особистості як динамічної системи ставлень людини до дійсності [8].

Згідно $з$ цією теорією, ставлення людини - це не частина особистості, а потенціал іiї психічної реакції (переживань і дій) щодо якогось предмета, процесу або факту дійсності. Поняття психічного ставлення відображає внутрішній бік зв'язку людини з дійсністю, змістово характеризує особистість як активного суб' єкта з його вибірковим характером внутрішніх переживань і зовнішніх дій, спрямованих на різні сторони об'єктивної дійсності. Діяльність і поведінка однієї і тієї ж особистості в кожен конкретний момент визначаються іï ставленнями до різних сторін дійсності, ставленнями, що випливають також з історії розвитку особистості [там само, с. 49].

Ставлення $є$ цілісним, як і сама особистість. Розвиток особистості - це процес налагодження іiі зв'язків 3 дійсністю, що постійно ускладнюються, збагачуються, поглиблюються. Це розвиток й ускладнення психічних процесів і формування досвіду (психічного потенціалу). Досвід набувається у формі накопичення: 1) знань; 2) навичок; 3) умінь; 4) ставлень. Усі чотири види потенційного психічного тією чи іншою мірою характеризують особистість. Дослідження особистості в ії розвитку - це історичне вивчення особистості в динаміці іiі змістових ставлень [там само, с. 49]. Так само це стосується і до вивчення політикоправової свідомості особистості, де предметом дослідження є динамічна система ставлень людини до відповідних аспектів політико-правової дійсності. 
Оскільки ставлення існують між особистістю - суб'єктом - і об'єктом її ставлень, то вони реалізуються (і можуть вивчатися) у ситуації взаємодії людини з олюдненим світом. I структурно-змістовий, і процесуальний підходи до вивчення ППС аналізують вияви особистісних ставлень людини до політико-правової дійсності: перший - змістові характеристики наявної системи ставлень, другий - способи конструювання цієї системи. Феноменологічний підхід спрямований на вивчення надситуативних характеристик функціонування особистості як системи ставлень людини до дійсності - інтегральних властивостей системи, які зумовлюють типовий для неї сценарій вирішення життєвих завдань (у нашому дослідженні - завдань політико-правового плану).

Найчастіше для категоризації цих феноменів у психологічній науці застосовують поняття спрямованості особистості, запропоноване В. Штерном [9]. "Характеристика особистості їі спрямованістю є топографічно-векторною, у застосуванні до психології це означає домінуюче ставлення" [8, с. 150]. Використання поняття “спрямованість” викликає питання не тільки про те, що є тим, на що спрямована людина, а й що саме спрямоване. Так, говорять про спрямованість смаків, поглядів, бажань, мрій, інтересів, симпатій, схильностей і т. ін. Спрямованість інтересів - коректне поняття, воно характеризує домінуючі інтереси особистості.

Утім, говорити про “спрямованість” особистості дуже складно, адже особистість багатогранно вибіркова. "Особистість має характеристики не лінійні і не площинні. Якщо користуватися просторовою метафорою, особистість являє собою не тільки тривимірну величину, як статуя, але, як усе живе, вона динамічна і по-різному в різних системах змінюється в процесі життя. Характеристика особистості через спрямованість не тільки є односторонньою і збідненою, а й малопридатною для розуміння більшості людей, поведінка яких визначається зовнішніми впливами та відсутністю «керма» домінуючої спрямованості. Ставлення людини різноманітні, а тому саме вони можуть розкрити різноманітність людської психіки" [там само, с. 150].

Те ж саме можна сказати і про поняття "якість" особистості. Кожна людина має цілу низку особистісних "якостей”, які виявляються різними гранями в різних ситуаціях та об'єднуються в нові композиції залежно від обставин ситуації в їхній даності суб'єктові взаємодії. А оскільки одна й та сама особистісна “якість” виявляється в одних ситуаціях і не виявляється в інших, то вона $є$ не так психологічним утворенням, як виявом того, як особистість конструює певну комунікативну ситуацію взаємодії (комунікативну ситуацію). Класичним прикладом того, як у ситуації опитування люди демонструють одні якості, а на практиці - протилежні, $є$ експерименти С. Лап'єра Під час цих експериментів у поведінкових виявах більшості досліджуваних не виявлялася “якість" расової нетерпимості, яку вони самі собі приписували. 
Більш коректним для опису інтегральної схильності особистості до тих чи тих варіантів конструювання дійсності $\epsilon$, на наш погляд, поняття “особистісна позиція". Введене в ужиток ще А. Адлером (A. Adler, 1912), це поняття “являє собою, по суті, інтеграцію домінуючих вибіркових ставлень людини до значущих для неї питань" [там само, c. 150]. Якщо певні завдання вибору періодично постають перед людиною, то в кумулятивному плані можна виявити схильність особистості до вибору тієї чи тієї позиції щодо вирішення цих завдань. Коли ж ідеться про завдання самовизначення у владно-підвладних відносинах, то можна говорити про такі особистісні позиції, як “лояльність - критичність”, “громадянська активність - пасивність”, “схильність до автономності - запит на патерналізм”, “колективізм - індивідуалізм”, “консерватизм - радикалізм" тощо.

Той факт, що це не “якості” і не “спрямованості” особистості, а саме тимчасова тенденція в обиранні нею певної позииї у вирішенні життєвих завдань, підтверджується численними науковими дослідженнями, які показують змінюваність цих тенденцій залежно від соціальних, економічних чи політико-правових обставин життя спільнот (Ф. Васбурн, А. Дроздова, А. Зоткін, А. Колоколова, А. Крилов).

Близьким до поняття “позиція" $є$ поняття “настановлення”, введене в ужиток Л. Ланге (L. Lange, 1888). Воно розроблялося в психологічній теорії “атитюдів” й активно досліджувалося школою Д. Узнадзе. Поняття “настановлення" відображає психологічний стан схильності суб'єкта до певної активності в певній ситуації. Проте слід розрізняти “сенсомоторні настановлення”, які є “безособистісним” виявом інерції перебігу психічних процесів і виробляються експериментально, і поняття “особистісні настановлення”. Д. Узнадзе, який на прикладі сенсомоторних настановлень ілюстрував вплив "інерції минулого" на подальші реакції досліджуваних, визначав це поняття як готовність особистості до певної, зумовленої потребою, діяльності, як механізм інтегрування життєвого досвіду в теперішні реакції особистості. Таке розуміння поняття “особистісні настановлення", прийняте в сучасній психології, включає разом з інерцією очікувань також інтерпретацію теперішнього і прогнозування майбутнього [10]. У цьому розумінні в "настановленні" особистості інтегруються ї̈ домінуючі ставлення до дійсності, як і в понятті "особистісна позиція".

Якщо ми стверджуємо, що психологічним змістом патріотизму, патерналізму, правового нігілізму тощо $є$ ті ставлення до дійсності, які реалізує людина, вирішуючи певну множину життєвих завдань (зокрема завдань політико-правової ідентифікації), то це дає нам змогу солідаризувати різнопланові наукові тлумачення цих феноменів. Оскільки суб'єктивні ставлення є латентним потенціалом переживань і дій людини в картині світу, то вияви цих ставлень можуть досліджуватися 
наукою і як переживання (стани, настрої), і як патерни поведінки (готовність до певних дій, сценарії взаємодії).

У наукових колах наразі активно точиться дискусія про те, як розвиток політико-правової свідомості особистості пов'язаний з тими чи іншими іiї настановленнями. Наприклад, патріотична позиція особистості трактується не тільки як корелят ii громадянської зрілості (А. Овчаров, О. Петрунько), а і як компенсаторно-захисний спосіб підвищення відчуття власної цінності, спосіб зняття відповідальності за здійснювані політико-правові вибори (В. Васютинський, О. Вознесенська, Н. Череповська, Е. Грицай, М. Ніколко). Це ж саме стосується і патерналізму, який розглядається в психології і як самообмеження особистісної автономності (М. Дубинянський, Е. Лібанова, Т. Петрушина,), i як закономірні очікування турботи від влади людьми, яких ця ж влада позбавила можливостей жити 3 власної праці (М. Колоколова, О. Бєлінська, Т. Стефаненко). Сучасні соціально-психологічні дослідження свідчать про те, що патерналістські настановлення не корелюють 3 особливостями ціннісних орієнтацій та структурою самоідентифікації особистості, а залежать від міри соціальної захищеності громадян. Так, в умовах зростання корупції, інфляції, безробіття, податкового тиску на підприємницьку діяльність істотно звужуються можливості пересічного громадянина реалізувати свої конституційні права (на працю, житло, освіту, медицину, судовий захист тощо), що змушує його відмовлятися від автономності.

Більшість із цих дискусійних теоретичних питань можна було б, на наш погляд, зняти, якщо визнати, що всі описані соціально-психологічні феномени має сенс розглядати як інтеграцію домінуючих ставлень людини до дійсності. Залежно від того, наскільки зрілою (усвідомленою, диференційованою, інтегрованою, когерентною) є динамічна система особистісних ставень, залежить і те, наскільки сформована 3 них "особистісна позиція” буде адекватною ситуації та продуктивною для розвитку суб'єкта і суспільства. Якщо вихідні ставлення “незрілі” (когнітивно не опрацьовані, інтроектовані, суперечливі, стереотипні, розмиті), то й будь-яка їх інтеграція буде такою ж ущербною. Тобто ресурсність таких особистісних позицій, як патріотизм, патерналізм, лояльність, переконаність тощо залежить від того, хто і коли (в яких ситуаціях) їх реалізує. Отже, немає жодних підстав оцінювати корисність “патріотизму” або шкідливість “патерналізму” абстрактного громадянина, оскільки жодна інтеграція домінуючих ставлень не схожа на іншу, а також не може бути завжди конструктивною (так само як і деструктивною).

У межах феноменологічного наукового підходу вирішується передусім питання про те, які особистісні позиції схильна посідати людина, здійснюючи свої життєві вибори. Кількість феноменів, які може виокремити наука для узагальнення особливостей настановлення 
особистості на певні варіанти виборів, є необмеженою. В основі всіх цих особистісних настановлень лежать змістові ставлення людини до дійсності. Таким чином, у будь-якій інтеграції домінуючих ставлень особистості до політико-правових виборів представлені ставлення людини: до себе (як суб' єкта пізнання та перетворення світу), до політичних об'єктів $і$ явищ (образ реальної та бажаної політико-правової дійсності), до сиенаріїв реалізаиії себе в соиіумі (отримані із соціального та індивідуального досвіду моделі владно-підвладної взаємодії). Те, що визначається в психології як "особистісна позиція" або “настановлення особистості", є феноменом (сумарним виявом) актуалізації ичих ставлень у певній множсиі здійснюваних людиною політико-правових виборів.

Оскільки визначити таку надситуативну позицію особистості, тільки знаючи про окремий ії вибір, неможливо, то методом вивчення властивих людині настановлень $є$ глибинні інтерв'ю та розгорнуті самозвіти, в яких респонденти висвітлюють ті “теми”, переживання і рішення, що повторюються в їхньому житті. Створюючи стандартизовані опитувальники, їхні розробники намагаються ставити "рефлексивні" питання, за якими респонденти мають оцінити такі ж самі свої узагальнені ставлення. Наприклад, Опитувальник рівня патерналізму щодо інститутів влади Т. Стефаненко дає змогу з'ясувати характеристики таких суб' єктивних ставлень людини до дійсності, як “міфологізація влади”, “абсолютизація закону”, “потреба в опіці і захисті" та "прагнення зняти відповідальність за власні вибори” [11]. За умови, що всі ці ставлення є домінуючими та актуалізуються у відповідній картині світу, складений $з$ них інтеграл самовизначення особистості в ситуації можна вважати виявом іiі “патерналістичних настановлень”. Проте на основі таких тестових відповідей дуже складно стверджувати, що всі декларовані респондентом ставлення є домінуючими, а не декларовані не існують взагалі. Перші можуть виявитися ситуативними, а другі неусвідомлюваними. Якщо вже й покладатися на самоаналіз досліджуваних, то коректно було б ставити питання безпосередньо про ті ставлення, які вивчаються. Наприклад, запропонувати реальну або умовну ситуацію, в якій досліджуваним треба зробити вибір 3-поміж двох можливих альтернатив (за чи проти реалізації певних настановлень).

Оскільки в кожному з описаних наукових підходів розкриваються специфічні аспекти функціонування свідомості, то результатом цих досліджень стає виділення й специфічних груп соціально-психологічних чинників становлення ППС. Так, структурно-змістовий підхід, який вивчає характеристики наявної системи ставлень людини до дійсності, розглядає структурно-змістові чинники становлення ППС; процесуальний підхід, зосереджений на вивченні способів конструювання цієї системи, виділяє комунікативні чинники становлення ППС; феноменологічний підхід, спрямований на визначення надситуативних харак- 
теристик функціонування особистості як суб'єкта політико-правового самовизначення, досліджує функиіональні чинники становлення ППС.

Висновки. На основі теоретичного аналізу наукових підходів до вивчення політико-правової свідомості виділено три групи соціальнопсихологічних чинників їі становлення: структурно-змістові, комунікативні та функціональні. Кожна група вирізняється своєю структурою взаємозв’язків і відносною значущістю окремих чинників. Віднесення певного соціально-психологічного чинника становлення ППС до тієї чи тієї групи визначається тим, що вивчення кожного з них є втіленням відповідного наукового виміру реальності, а отже, потребує застосування адекватних цьому теоретичному підходу емпіричних методів дослідження та інтерпретаційних схем.

Перспективи подальших досліджень полягають у тому, щоб емпірично дослідити психологічні чинники становлення ППС, застосувавши адекватні запропонованій методології методи.

\section{Список використаних джерел}

1. Швалб, Ю. М. (2004). Свідомість як відношення людини до світу. Психологія і суспільство, 4, 160-169.

2. Фуко, М. (2011). Управление собой и другими. Курс лекций, прочитанных в Коллеж де Франс в 1982-1983 учебном году. Санкт-Петербург: Наука.

3. Marcia, J. E. (1980). Identity in adolescence In J. Adelson (Ed.). Handbook of adolescent psychology (pp. 159-187). New York: John Wiley.

4. Титаренко, Т. М. (2017). Особистість перед викликами війни: психологічні наслідки травматизації. Проблеми політичної психологї̈, 5 (19), 3-11.

5. Роджерс, К., \& Фрейберг, Дж. (2002). Свобода учиться. Москва: Смысл.

6. Осадько, О. Ю. (2011). Когнітивно опосередковані засоби "психологічного захисту" вчителя у психотравмуючих ситуаціях професійного спілкування. В В. П. Казміренко (Ред.), Активізація когнітивних процесів у спілкуванні (с. 76-120). Київ: Міленіум.

7. Осадько, О. Ю. (2014). Фасилітаційно-орієнтоване спілкування як спосіб психологічної допомоги особистості в освоєнні соціальних протиріч. Матеріали II Всеукраӥнської науково-практичної конферениї “Реєстри стосунків II” (13-14 грудня 2014 р., м. Київ) (с. 67-80). Київ: КНУ ім. Тараса Шевченка.

8. Мясищев, В.Н.& Бодалев, А. А. (Ред.). (1995). Психология отношений. Избранные психологические труды. Москва: Ин-т практ. психологии; Воронеж: Модэк.

9. Stern, W. (1968). Personalistische Psychologie. (In: Einführung in die neuere Psychologie. Harz, 1931, In: B. B. Wolman (Ed.), Historical roots of contemporary psychology, chap. 15. New York.

10. Макклелланд, Д. (2007). Мотивация человека. Санкт-Петербург: Питер.

11. Стефаненко, Т.Г. (2001). Изучение идентификационных процессов в психологии и смежных науках. В Т. Г. Стефаненко (Ред.), Трансформация идентификационных структур в современной России (с. 11-29). Москва: Московский общественный научный фонд. 


\section{References}

1. Shvalb, Yu. M. (2004). Svidomist yak vidnoshennia liudyny do svitu [Consciousness as a person's relation to the world]. Psykholohiia i suspilstvo [Psychology and Society], 4,160-169 (ukr).

2. Fuko, M. (2011). Upravleniye soboy i drugimi. Kurs lektsiy, prochitannykh $v$ Kolledzh de Frans v 1982-1983 uchebnom godu [Managing ownself and others. Course of lectures read at the College de France in the 1982-1983 academic year]. St. Petersburg: Nauka Publ. (rus).

3. Marcia, J. E. (1980). Identity in adolescence In J. Adelson (Ed.). Handbook of adolescent psychology (pp. 159-187). New York: John Wiley.

4. Tytarenko, T. M. (2017). Osobystist pered vyklykamy viyny: psykholohichni naslidky travmatyzatsii [Personality upon the challenges of war: the psychological consequences of traumatisation]. Problemy politychnoi psykholohii [Problems of Political Psychology], 5 (19), 3-11 (ukr).

5. Rogers, K., \& Freiberg, G. (2002). Svoboda uchitsya [Freedom to learn]. Moscow: Smysl Publ. (rus).

6. Osadko, O. Yu. (2011). Kohnityvno oposeredkovani zasoby "psykholohichnoho zakhystu" vchytelia u psykhotravmuiuchykh sytuatsiiakh profesiinoho spilkuvannia [Cognitively mediated means of "psychological defence" of a teacher in traumatic situations of professional communication]. In V. P. Kazmirenko (Ed.), Aktyvizatsiia kohnityvnykh protsesiv u spilkuvanni [Activation of cognitive processes in communication] (pp. 76-120). Kyiv: Millenium Publ. (ukr).

7. Osadko, O. Yu. (2014). Fasylitatsiino-oriientovane spilkuvannia yak sposib psykholohichnoi dopomohy osobystosti $\mathrm{v}$ osvoienni sotsialnykh protyrich [Facilitation-oriented communication as a way of psychological assistance of the individual in the familiarization with social contradictions]. Materialy II Vseukrainskoi naukovo-praktychnoi konferentsii "Reiestry stosunkiv II" (1314 hrudnia 2014, Kyiv) [Materials of the 2nd All-Ukrainian Scientific and Practical Conference "Registers of Relationships II" (December 13-14, 2014, Kyiv)] (pp. 67-80). Kyiv: KNU named Taras Shevchenko (ukr).

8. Myasischev, V. N., \& Bodalyov, A. A. (Ed.). (1995). Psikhologiya otnosheniy. Izbrannyye psikhologicheskiye trudy [Psychology of relationships. Selected psychological works]. Moscow: Institute of practical psychology; Voronezh: Modek Publ. (rus).

9. Stern, W. (1968). Personalistische Psychologie. (In: Einführung in die neuere Psychologie. Harz, 1931). In: B. B. Wolman (Ed.), Historical roots of contemporary psychology, chap. 15. New York.

10. Makklelland, D. (2007). Motivatsiya cheloveka [Human motivation]. St. Petrsburg: Piter Publ. (rus).

11. Stefanenko, T. G. (2001). Izucheniye identifikatsionnykh protsessov v psikhologii i smezhnykh naukakh [The study of identification processes in psychology and related sciences]. In T. G. Stefanenko (Ed.), Transformatsiya identifikatsionnykh struktur v sovremennoy Rossii [Transformation of identification structures in modern Russia] (pp. 11-29). Moscow: Moscow Public Science Foundation (rus).

(C) Сіверс 3. Ф. 